\title{
Sağlıklı Kişilerde Konnektif Doku Manipulasyonunun Otonom Sinir Sistemi Üzerindeki Akut Etkilerinin Değerlendirilmesi
}

\author{
Özge VERGILII $\dot{I}^{1}$ ve Inci YÜKSEL $L^{2}$ \\ ${ }^{1}$ Kırlkkale Üniversitesi, Sağllk Bilimleri Fakültesi, Fizyoterapi ve Rehabilitasyon Ab..D, kocaacar@yahoo.co.uk \\ ${ }^{2}$ Hacettepe Üniversitesi, Sağllk Bilimleri Fakültesi, Fizyoterapi ve Rehabilitasyon Bölümü
}

\begin{abstract}
Özet
Çalışmamızda tek seanslık konnektif doku manipulasyonunun otonom sinir sistemi üzerindeki akut etkisinin değerlendirilmesi amaçlandı. Bu çalışmaya on sekiz yaşını doldurmuş altmış sağlıklı kadın alınarak olgular randomize olarak iki gruba ayrıldı. Birinci gruba konnektif doku manipulasyonu, ikinci gruba ise plasebo konnektif doku manipulasyonu uygulaması bir seans için yapılarak, uygulamaların otonom sinir sistemi üzerindeki akut etkisine bakıldı. Otonom sinir sistemi ölçüm parametreleri olarak kalp hızı, kan basıncı, solunum frekansı ve periferik deri temperatürü göz önüne alındı. İstatistiksel analizler sonucunda konnektif doku manipulasyonu ve plasebo konnektif doku manipülasyonu uygulamalarının otonom sinir sistemi üzerinde herhangi bir akut etkisinin olmadığı $(\mathrm{p}>0,05)$ görüldü. Tek seanslık konnektif doku manipulasyonu uygulamasının otonom sinir sistemi üzerinde akut etki oluşturmada yetersiz kaldığı görüldü.
\end{abstract}

Anahtar Kelimeler: Konnektif doku manipulasyonu, plasebo, otonomik.

\section{Evaluation of The Acute Effects of Connective Tissue Manipulation on The Autonomic Nervous System for Healthy Humans}

\begin{abstract}
In our study we aimed to evaluate the acute effect of one-session connective tissue manipulation on autonomic nervous system. Sixty healthy women older than eighteen years were enrolled in this study and they were randomly divided into two groups. A single connective tissue manipulation was applied to the first group, while a single plasebo connective tissue manipulation was applied to the second group and the acute effect of the applications on the autonomic nervous system were observed. Heart rate, blood pressure, respiration frequency and peripheral skin temperature were considered as autonomic measurement parameters. The statistical analyses showed that neither connective tissue manipulation, nor plasebo connective tissue manipulation procedures revealed any acute effect on autonomic nervous system $(p>0,05)$. It was shown that the one-session connective tissue manipulation application was insufficient to reveal any acute effect on autonomic nervous system.
\end{abstract}

Keywords: Connective tissue manipulation, placebo, autonomic. 


\section{Giriş}

Masaj, vücudun yumuşak dokuları üzerine sistematik ve bilimsel olarak uygulanan bir manipulasyon türüdür. Masajın uygulanmasındaki amaç, bir takım fizyolojik, mekanik, refleks ya da psikolojik etkiler meydana getirmektir (Tapan, 1988). Masaj tedavisinin farklı formları bulunmaktadır. Klasik masaj, konnektif doku manipulasyonu (KDM) (Tapan, 1988), su altı masaj1, shiatsu ve acupressure kullanılan tekniklerden bazılarıdır (Callaghan, 1993). KDM ise otonom sinir sistemi (OSS) üzerindeki etkisi nedeni ile tercih edilen bir manual tedavi tekniğidir (Akbayrak, 2001; Holey, 2000). KDM, otonomik sinir sonlanmalarını uyarmak ve OSS'nin sempatik ve parasempatik kısımları arasındaki dengeyi düzenlemek amacı ile konnektif doku üzerine uygulanan ve refleks etkileri olan bir tedavi şeklidir (Holey, 2000). KDM'de kullanılan manual çekmeler belirli anatomik noktalara belirli bir sıra takip edilerek yapılmaktadır (Tapan, 1988). Literatürde KDM'nin gerek tek başına, gerekse diğer fizyoterapi yöntemleri ile birlikte kullanımına ilişkin klinik sonuçlar yer almaktadır (Akbayrak ve ark., 2001). Ancak, KDM'nin etkin bir manual tedavi tekniği olmasının ardında, OSS üzerindeki olası etkisi henüz net olarak ortaya konulamamıştır. Yapmış olduğumuz çalışma ile, sağlıklı popülasyonda KDM'nin OSS üzerindeki olası akut etkisinin ortaya konulması amaçlanmıştır.

\section{Deneysel Model}

Bu çalışma, Hacettepe Üniversitesi Tıp Fakültesi Tıbbi, Cerrahi ve İlaç Araştırmaları Etik Kurulu'nca tıbbi etik açıdan uygun bulunmuştur. Çalışmaya alınan bireyler on sekiz yaşını doldurmuş, bilinen herhangi bir kardiyovasküler, nörolojik, metabolik vb. OSS disfonksiyonuna neden olacak hastalığı olmayan sağlıklı kişiler olup, olguların seçiminde basit rastgele örnekleme yöntemi kullanıldı. OSS yanıtlarını etkileyebilecek olması ihtimali ile, düzenli ilaç kullanımı olan, akut inflamasyon, malignansi gibi KDM uygulamasına kontra endikasyonu olan bireyler çalışmaya alınmadı. Çalışmaya dahil edilmiş olan tüm olgular çalışmaya gönüllü olarak katılım göstermiş olup, kendilerinden bilgilendirilmiş onam formu alındı. Çalışmaya alınan altmış birey randomize olarak KDM $(n=30)$ ve plasebo KDM $(n=30)$ gruplarına ayrıldı. Gruplardan birindeki bireylere KDM ve diğer gruptaki bireylere de plasebo KDM yalnızca bir seans için uygulanarak, uygulamaların OSS üzerindeki akut etkilerine bakıldı. OSS cevaplarını değerlendirme parametreleri olarak bireylerin kalp hızı, sistolik ve diastolik kan basıncı, solunum frekansı ve periferik deri temperatürü değerleri kullanıld.

\section{KDM Uygulaması}

Çalışmada otonomik fonksiyonların değerlendirilmesi söz konusu olduğu için, otonomik cevapları etkileyebilen faktörler kontrol altında tutuldu. Bu amaç ile, çalışmanın yapıldığı odanın ısısı, 1sitic1 bir ajan ile sabit tutuldu $\left(22-24 \mathrm{C}^{\circ}\right)$ (oda 1sis1 termometre ile kontrol edildi). Bireyler, psikofizyolojik yanıtlarının stabilleşmesi amacı ile çalışma prosedürüne başlamadan önce uygulama pozisyonunda ve sırtları açık olarak on beş dakika boyunca dinlendirilerek, çalışma süresince ani vücut hareketleri ile postür değişikliklerinden kaçınmaları sağlandı. Çalışmaya alınan bireylerde bilinen herhangi bir hastalı ya da bozukluk olmaması nedeni ile uygulama spesifik olarak herhangi bir ekstremiteye yönlendirilmedi. Bu gruptaki kişilere bir seanslık KDM temel bölge, alt torakal bölge, skapular bölge, interskapular bölge, servikal bölge, oksipital bölge olmak üzere tüm sırtı içerecek şekilde uygulandı. Uygulamada teknikte tanımlandığı şekilde ilgili bölgelere uygun çekmeler (uzun ya da kısa) uygun bir sırada tatbik edildi. Uygulama sırasında kişiler sırtları açık olarak, sırt ve kol desteği olmayan bir taburede, gövde ile kalçalar ve kalçalar ile dizler arasında doksanar derecelik açı olacak şekilde dik bir pozisyonda oturtuldu. Yapılan KDM uygulaması yaklaşık olarak on beş dakikada tamamland.

\section{Plasebo KDM Uygulaması}

Bu gruptaki kişilere normal KDM uygulaması ile aynı çalışma ortamı koşullarında ve aynı fizyoterapist tarafindan plasebo KDM uygulandı. Plasebo KDM uygulaması, normal KDM uygulaması ile, bireylerin tedavi pozisyonları, çekmelerin derinliği ve karakteri (subkuten dokuda germe oluşturan) ve uygulama süresi açısından benzer şekilde yapıldı. Tek farklılık olarak, plasebo 
KDM uygulamasındaki çekmeler anatomik uygunluğa dikkat edilmeksizin gelişigüzel bir uygulama modelinde yapıldı. Çekme yapılan bölgeler tamamen rastgele bir biçimde seçildi. Normal KDM uygulamasındakine benzer olarak her bir çekme üçer kez tekrar edildi. Bu gruptaki tüm bireylere aynı model uygulanarak, tüm bireyler aynı anatomik özellikte ve sırada çekmelere tabi tutuldu. Uygulama bölgeleri seçilirken otonomik sinir sonlanmalarının zengin olduğu ve KDM'de sıcça kullanılan paravertebral sahaların kullanılmamasına ve böylelikle uygulamaya plasebo niteliği kazandırılmasına dikkat edildi (8-11). Uygulama yapılırken, KDM'deki gibi sakral bölgeden başlayıp sıra ile yukarı çıkılmamış olup, aksine herhangi bir sıra izlemeden, sırtın bir proksimalinden, bir distalinden seçilen gelişi güzel bölgelere çekme yapıldı. KDM'de olduğu gibi bu uygulamada da vücudun her iki tarafına aynı çekmeler resiprokal olarak uygulandı.

\section{Değerlendirme Süreci}

Her iki gruptaki bireyler, on beşer dakikalık iki farklı uygulamaya tabi tutuldu. Uygulamaların OSS üzerindeki etkisini, diğer faktörlerden bağımsız olarak değerlendirebilmek amacı ile, her birey aynı zamanda kendisinin kontrolü olarak kullanıldı. Bu amaçla uygulamalara geçilmeden önce, uygulamanın yapıldığı pozisyonda ve ortam koşullarında, uygulama ile aynı süre boyunca (on beş dakika) ve aynı zaman aralıklarında $(1 ., 3 ., 5 ., 10 ., 15$.$) kişi manual uyarı almaksızın otururken,$ otonomik yanıtlardan kalp hızı, kan basıncı, solunum frekansı ve periferik deri temperatürü ölçülerek değerleri kaydedildi (kontrol periyodu). Ardından uygulama boyunca 1.,3.,5.,10.,15. dakikalarda (uygulama periyodu) ve uygulamayı takip eden otuz dakikalık istirahat boyunca (takip periyodu) 1.,3.,5.,10.,15.,20.,25.,30. dakikalarda aynı ölçümler yapılarak değerler kaydedildi.

\section{Ölçüm Parametreleri ve Araçları}

OSS cevaplarının değerlendirilmesinde ölçüm parametreleri olarak kalp hızı, sistolik kan basıncı, diastolik kan basıncı, solunum frekansı ve periferik deri temperatürü kullanıldı. Kalp hızı ile kan basıncı değerleri "Braun" marka dijital kan basıncı ölçüm aracı ile (Şekil 1), periferik deri temperatürü ise "GSR/TEMP 2X" setinin ilgili aparatları ile, aletin 1sı sensörü sağ elin ikinci parmağının ucuna tesbit edilerek ölçüldü (Şekil 2). Solunum frekansı değeri ise, otuz saniye süresince alıp verilen soluk sayısının iki ile çarpılması ile elde edildi.

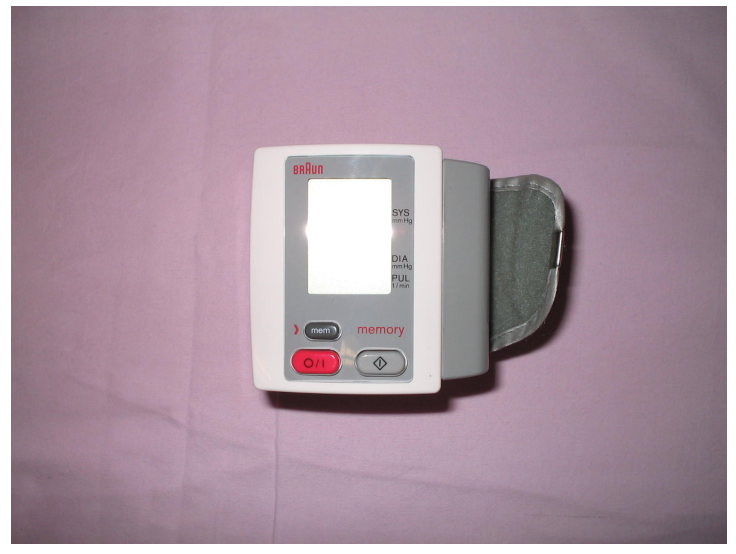

Şekil 1. Kan Basıncı Ölçüm Aracı

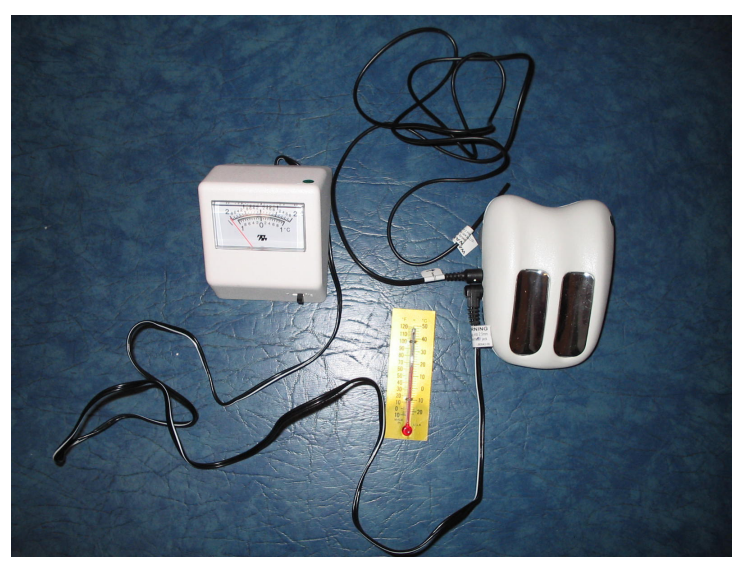

Şekil 2. GSR/TEMP 2X Seti

\section{Çalışmada Kontrol Edilen Koşullar}

Plasebo kontrollü bu çalışmada tek körlemeli deney düzeni kullanıldı. Çalışmaya alınan her birey psikofizyolojik yanıtlarının stabilleşmesi amacı ile on beş dakika boyunca uygulamanın yapılacağı odada, uygulama pozisyonunda ve sırtı açık olarak dinlendirilerek, çalışma prosedürüne bu istirahati takiben başlandı. OSS üzerindeki olası etkilerinden dolayı, bireylere çalışmaya gelmeden önce alkol, 
sigara, kafeinli içecek tüketmemeleri ve egzersiz yapmamaları konusunda hatırlatma yapıldı (Kawano, 1999; Seals ve Chase, 1989). Yine çalışma boyunca otonomik yanttarın etkilenmemesi amacı ile kişilerin postürlerini değiştirmemelerine ve ani vücut hareketlerinden kaçınmalarına dikkat edildi (Rajendra ve ark., 2005; Akselrod ve ark., 1997).

\section{İstatistiksel Analiz}

Çalışmadan elde edilen verilerin analizinde "SPSS 11.5 for Windows" istatistik programı kullanıldı. Grup içi ve gruplar arası farklılıklar araştırılırken, iki gruba ait parametrik ve nonparametrik veriler "Bağımsız Gruplarda T Testi" ve "Mann-Whitney U Testi" ile; İkiden çok sayıda bağımsız gruba ait non-parametrik veriler "Kruskal Wallis Varyans Analizi" ile; bir gruptaki iki zaman ya da duruma ait parametrik veriler "İki Eş Arasındaki Farkın Önemlilik Testi" ile; bir gruptaki ikiden çok zaman ya da duruma ait parametrik veriler "Tekrarlı Ölçümlerde Varyans Analizi" ile karşılaştırıldı. Tüm karşılaştırmalar için yanılma olasılığı olarak $\alpha=0,05$ seçildi. Tekrarlı Ölçümlerde Varyans Analizinde Zaman; değişkenin zaman içindeki değişimine, Zaman x Uygulama; değişkende meydana gelen değişimin gruplarda benzer ya da farklı oluşuna, Uygulama; değişkenin ölçüm yapılan tüm zamanlardaki ortalamasının gruplarda benzer ya da farklı oluşuna işaret etti.

\section{Modelden Çıkan Sonuçlar}

Yaş, boy, kilo ve vücut kitle indeksi göz önüne alındığında, yalnızca yaş ortalaması açısından iki grup arasındaki fark anlamlı bulundu (Tablo 1). Bu yaş farkı ise klinik açıdan çalışmamızın sonuçlarını etkileyecek bir öneme sahip değildi. Uygulamaların OSS üzerindeki etkisi, her bir uygulama kendi kontrol periyodu ile kıyaslanarak incelendiğinde, KDM ya da plasebo KDM'nin OSS üzerinde akut bir etkisi olmadığ 1 görüldü (plasebo KDM grubunda yalnızca uygulamanın beşinci dakikasındaki kalp hızı kontrolden daha düşük bulundu). Gerek kontrol ve gerekse uygulama periyodlarında, KDM ve plasebo KDM gruplarındaki bireylerin, solunum frekansı değerlerinde meydana gelen azalmalar ile, periferik deri temperatüründe meydana gelen artışlar benzer düzeyde seyretti (periferik deri temperatürü değerleri, uygulama periyodu boyunca ve kontrol periyodunun sifir ve onuncu dakikalarında plasebo KDM grubunda daha yüksek seyretti). Uygulamaları takip eden otuz dakikalık kontrol periyodunun ilk on beş dakikası sempatik ya da parasempatik özellik göstermemiş olup, son on beş dakikası ise, gruplarda periferik deri temperatürünün hızla düşmesi ve diastolik kan basıncının yükselmesi ile birlikte sempatik özellik gösterdi (Tablo 2 -10).

Tablo 1. KDM Ve Plasebo KDM Olgularının Fiziksel Özelliklerinin Karşılaştırılması

\begin{tabular}{lllcc}
\hline Özellik & \multicolumn{1}{c}{$\begin{array}{c}\text { Kontrol(n=30) } \\
\text { Ort } \pm \text { SS }\end{array}$} & $\begin{array}{c}\text { Çalışma(n=30) } \\
\text { Ort } \pm \text { SS }\end{array}$ & t & p \\
\hline Yaş $(\mathrm{y} 1 \mathrm{l})$ & $23,63 \pm 2,33$ & $21,90 \pm 1,67$ & 3,32 & $0,00^{*}$ \\
Boy $(\mathrm{cm})$ & $164,73 \pm 6,11$ & $164,07 \pm 6,27$ & 0,42 & 0,68 \\
Vücut Ağırlığı $(\mathrm{kg})$ & $56,43 \pm 6,51$ & $53,70 \pm 5,68$ & 1,73 & 0,09 \\
VKİ $\left(\mathrm{kg} / \mathrm{m}^{2}\right)$ & $20,77 \pm 1,79$ & $20,01 \pm 2,41$ & 1,38 & 0,17 \\
\hline
\end{tabular}

$* \mathbf{p}<\mathbf{0 , 0 5}$

Tablo 2. Tekrarlı Ölçümlerde Varyans Analizi Sonuçları - Kalp Hızl-

\begin{tabular}{lcc}
\hline Kalp Hızı & F & p \\
\hline zaman & 3,108 & $0,00^{*}$ \\
zamanxuygulama & 2,249 & $0,01^{*}$ \\
uygulama & 0,377 & 0,54 \\
\hline
\end{tabular}

$* \mathbf{p}<\mathbf{0 , 0 5}$ 
Tablo 3. KDM Ve Plasebo KDM Gruplarındaki Kalp Hızı Değerlerinin Karşılaştırılması (Atım/Dakika)

\begin{tabular}{|c|c|c|c|c|}
\hline $\begin{array}{l}\text { Kalp hızının ölçüm zamanı } \\
\text { (dakika) }\end{array}$ & $\begin{array}{l}\text { KDM } \\
\text { Ort } \pm \text { SS }\end{array}$ & $\begin{array}{l}\text { Plasebo KDM } \\
\text { Ort } \pm \text { SS }\end{array}$ & $\mathbf{t}$ & $\mathbf{p}$ \\
\hline Kontrol 0 & $81,93 \pm 10,85$ & $84,53 \pm 13,51$ & $-0,82$ & 0,41 \\
\hline Kontrol 1 & $82,23 \pm 9,99$ & $83,43 \pm 12,20$ & $-0,42$ & 0,68 \\
\hline Kontrol 3 & $83,73 \pm 10,00$ & $84,80 \pm 12,85$ & $-0,36$ & 0,72 \\
\hline Kontrol 5 & $84,13 \pm 7,74$ & $85,17 \pm 11,97$ & $-0,40$ & 0,69 \\
\hline Kontrol 10 & $83,97 \pm 9,03$ & $82,80 \pm 12,16$ & $-0,42$ & 0,67 \\
\hline Kontrol 15 & $83,33 \pm 10,76$ & $82,30 \pm 11,25$ & $-0,36$ & 0,71 \\
\hline Uygulama 1 & $79,63 \pm 9,72$ & $78,73 \pm 11,46$ & $-0,33$ & 0,74 \\
\hline Uygulama 3 & $85,40 \pm 12,63$ & $79,17 \pm 12,64$ & 0,91 & 0,06 \\
\hline Uygulama 5 & $85,83 \pm 12,72$ & $78,10 \pm 10,76$ & 2,54 & $0,01 *$ \\
\hline Uygulama 10 & $85,07 \pm 14,39$ & $80,27 \pm 10,49$ & 1,48 & 0,14 \\
\hline Uygulama 15 & $82,20 \pm 8,33$ & $79,83 \pm 11,62$ & 0,91 & 0,37 \\
\hline Takip 1 & $79,67 \pm 10,33$ & $78,43 \pm 10,93$ & 0,45 & 0,65 \\
\hline Takip 3 & $81,90 \pm 9,40$ & $79,40 \pm 10,67$ & 0,96 & 0,34 \\
\hline Takip 5 & $84,00 \pm 12,22$ & $80,07 \pm 10,23$ & 1,35 & 0,18 \\
\hline Takip 10 & $81,27 \pm 10,95$ & $82,40 \pm 10,92$ & $-0,40$ & 0,69 \\
\hline Takip 15 & $80,17 \pm 9,19$ & $82,57 \pm 12,05$ & $-0,87$ & 0,39 \\
\hline Takip 20 & $79,27 \pm 10,44$ & $79,83 \pm 10,33$ & $-0,21$ & 0,83 \\
\hline Takip 25 & $80,53 \pm 9,46$ & $78,77 \pm 10,69$ & 0,68 & 0,50 \\
\hline Takip 30 & $83,97 \pm 9,84$ & $82,17 \pm 11,62$ & 0,65 & 0,52 \\
\hline
\end{tabular}

Tablo 4. Tekrarlı Ölçümlerde Varyans Analizi Sonuçlarl-Sistolik Kan Basıncı

\begin{tabular}{lcc}
\hline Sistolik Kan Basıncı & F & p \\
\hline zaman & 1,293 & 0,18 \\
zamanxuygulama & 1,334 & 0,16 \\
uygulama & 0,184 & 0,67 \\
\hline
\end{tabular}

Tablo 5. KDM ve Plasebo KDM Gruplarındaki Sistolik Kan Basıncı Değerleri (mm Hg)

\begin{tabular}{ll|l}
\hline $\begin{array}{l}\text { Sistolik kan basıncının ölçüm zamanı } \\
\text { (dakika) }\end{array}$ & $\begin{array}{l}\text { KDM } \\
\text { Ort } \pm \text { SS }\end{array}$ & $\begin{array}{l}\text { Plasebo KDM } \\
\text { Ort } \pm \text { SS }\end{array}$ \\
\hline Kontrol 0 & $109,13 \pm 9,93$ & $112,43 \pm 10,34$ \\
Kontrol 1 & $108,23 \pm 11,42$ & $110,93 \pm 10,43$ \\
Kontrol 3 & $109,10 \pm 10,04$ & $110,00 \pm 9,92$ \\
Kontrol 5 & $107,17 \pm 10,83$ & $109,00 \pm 9,35$ \\
Kontrol 10 & $109,97 \pm 9,26$ & $107,57 \pm 9,47$ \\
Kontrol 15 & $109,27 \pm 12,03$ & $108,37 \pm 10,61$ \\
Uygulama 1 & $107,77 \pm 9,92$ & $105,37 \pm 11,51$ \\
Uygulama 3 & $107,10 \pm 12,41$ & $107,40 \pm 12,20$ \\
Uygulama 5 & $109,43 \pm 15,30$ & $104,97 \pm 12,49$ \\
Uygulama 10 & $108,17 \pm 11,05$ & $108,10 \pm 9,91$ \\
Uygulama 15 & $107,60 \pm 9,35$ & $108,97 \pm 12,71$ \\
Takip 1 & $110,63 \pm 9,17$ & $108,13 \pm 9,41$ \\
Takip 3 & $108,03 \pm 8,75$ & $105,53 \pm 11,18$ \\
Takip 5 & $108,87 \pm 9,13$ & $106,17 \pm 9,70$ \\
Takip 10 & $109,13 \pm 10,83$ & $107,70 \pm 9,63$ \\
Takip 15 & $110,10 \pm 12,27$ & $107,67 \pm 10,39$ \\
Takip 20 & $109,63 \pm 9,92$ & $109,33 \pm 10,98$ \\
Takip 25 & $110,33 \pm 10,48$ & $106,00 \pm 11,16$ \\
Takip 30 & $109,70 \pm 11,78$ & $108,90 \pm 12,30$ \\
\hline
\end{tabular}


Tablo 6. Tekrarlı Ölçümlerde Varyans Analizi Sonuçlarl-Diastolik Kan Basıncı

\begin{tabular}{lcc}
\hline Sistolik kan basinc1 & $\mathrm{F}$ & $\mathrm{p}$ \\
\hline Zaman & 4,594 & $0,00^{*}$ \\
Zaman x Uygulama & 1,135 & 0,33 \\
Uygulama & 0,779 & 0,38 \\
\hline
\end{tabular}

$* \mathrm{p}<0,05$

Tablo 7. KDM Ve Plasebo KDM Gruplarındaki Diastolik Kan Basıncı Değgerleri (mm Hg)

\begin{tabular}{ll|l}
\hline $\begin{array}{l}\text { Sistolik kan basincının ölçüm zamanı } \\
\text { (dakika) }\end{array}$ & $\begin{array}{l}\text { KDM } \\
\text { Ort } \pm \text { SS }\end{array}$ & $\begin{array}{l}\text { Plasebo KDM } \\
\text { Ort } \pm \text { SS }\end{array}$ \\
\hline Kontrol 0 & $69,50 \pm 7,43$ & $71,17 \pm 10,87$ \\
Kontrol 1 & $67,40 \pm 7,76$ & $66,80 \pm 10,12$ \\
Kontrol 3 & $65,53 \pm 7,11$ & $64,23 \pm 9,66$ \\
Kontrol 5 & $64,90 \pm 6,96$ & $64,40 \pm 8,73$ \\
Kontrol 10 & $67,17 \pm 7,74$ & $64,80 \pm 9,98$ \\
Kontrol 15 & $66,80 \pm 10,51$ & $64,90 \pm 9,43$ \\
Uygulama 1 & $66,63 \pm 9,28$ & $66,73 \pm 11,62$ \\
Uygulama 3 & $65,73 \pm 9,07$ & $64,63 \pm 11,07$ \\
Uygulama 5 & $69,03 \pm 10,96$ & $65,73 \pm 11,35$ \\
Uygulama 10 & $67,93 \pm 7,99$ & $65,50 \pm 11,07$ \\
Uygulama 15 & $68,17 \pm 10,26$ & $66,13 \pm 11,30$ \\
Takip 1 & $67,50 \pm 8,42$ & $65,67 \pm 10,14$ \\
Takip 3 & $66,07 \pm 9,28$ & $66,60 \pm 12,49$ \\
Takip 5 & $68,93 \pm 9,31$ & $66,60 \pm 10,09$ \\
Takip 10 & $69,37 \pm 7,48$ & $66,83 \pm 9,49$ \\
Takip 15 & $68,20 \pm 8,94$ & $68,07 \pm 11,31$ \\
Takip 20 & $70,17 \pm 7,46$ & $67,23 \pm 11,09$ \\
Takip 25 & $71,10 \pm 7,63$ & $66,77 \pm 10,31$ \\
Takip 30 & $73,83 \pm 8,14$ & $68,37 \pm 10,86$ \\
\hline
\end{tabular}

Tablo 8. KDM Ve Plasebo KDM Gruplarındaki Solunum Frekansı Değerlerinin Karşılaştırılması (Sayı/Dakika)

\begin{tabular}{|c|c|c|c|c|}
\hline $\begin{array}{l}\text { Solunum frekansının ölçüm } \\
\text { zamanı (dakika) }\end{array}$ & $\begin{array}{l}\text { KDM } \\
\text { Ort } \pm \text { SS }\end{array}$ & $\begin{array}{l}\text { Plasebo KDM } \\
\text { Ort } \pm \text { SS }\end{array}$ & $\mathbf{z}$ & $\mathbf{p}$ \\
\hline Kontrol 0 & $20,40 \pm 4,08$ & $20,87 \pm 3,92$ & $-0,37$ & 0,71 \\
\hline Kontrol 1 & $20,90 \pm 3,68$ & $20,80 \pm 3,92$ & $-0,53$ & 0,60 \\
\hline Kontrol 3 & $20,73 \pm 3,78$ & $20,27 \pm 3,55$ & $-0,99$ & 0,32 \\
\hline Kontrol 5 & $19,93 \pm 3,58$ & $20,60 \pm 3,16$ & $-0,57$ & 0,57 \\
\hline Kontrol 10 & $20,00 \pm 4,03$ & $20,20 \pm 3,50$ & $-0,15$ & 0,88 \\
\hline Kontrol 15 & $19,63 \pm 3,59$ & $19,67 \pm 3,32$ & $-0,01$ & 0,99 \\
\hline Uygulama 1 & $20,40 \pm 3,74$ & $19,80 \pm 3,29$ & $-0,71$ & 0,47 \\
\hline Uygulama 3 & $20,33 \pm 3,25$ & $20,00 \pm 4,61$ & $-0,88$ & 0,38 \\
\hline Uygulama 5 & $19,77 \pm 3,71$ & $19,93 \pm 3,95$ & $-0,09$ & 0,93 \\
\hline Uygulama 10 & $19,40 \pm 3,46$ & $19,73 \pm 3,27$ & $-0,12$ & 0,91 \\
\hline Uygulama 15 & $19,67 \pm 3,80$ & $19,27 \pm 3,62$ & $-0,90$ & 0,37 \\
\hline Takip 1 & $19,20 \pm 3,04$ & $19,00 \pm 3,01$ & $-0,42$ & 0,67 \\
\hline Takip 3 & $19,17 \pm 3,88$ & $18,80 \pm 3,51$ & $-0,84$ & 0,40 \\
\hline Takip 5 & $19,60 \pm 3,54$ & $19,00 \pm 3,67$ & $-0,97$ & 0,33 \\
\hline Takip 10 & $19,07 \pm 3,18$ & $19,40 \pm 3,33$ & $-0,05$ & 0,96 \\
\hline Takip 15 & $19,37 \pm 3,13$ & $19,67 \pm 4,04$ & $-0,09$ & 0,93 \\
\hline Takip 20 & $19,73 \pm 3,06$ & $19,07 \pm 3,43$ & $-1,19$ & 0,23 \\
\hline Takip 25 & $19,57 \pm 3,41$ & $19,67 \pm 3,64$ & $-0,47$ & 0,64 \\
\hline Takip 30 & $19,17 \pm 2,92$ & $19,93 \pm 3,58$ & 0,61 & 0,54 \\
\hline
\end{tabular}


Tablo 9. KDM Ve Plasebo KDM Gruplarındaki Periferik Deri Temperatürü Değerlerinin Karşılaştırılması ( $\left.{ }^{0} \mathrm{C}\right)$

\begin{tabular}{|c|c|c|c|c|}
\hline $\begin{array}{l}\text { Periferik deri temperatürünün } \\
\text { ölçüm zamanı (dakika) }\end{array}$ & $\begin{array}{l}\text { KDM } \\
\text { Ort } \pm \text { SS }\end{array}$ & $\begin{array}{l}\text { Plasebo KDM } \\
\text { Ort } \pm \text { SS }\end{array}$ & $\mathbf{z}$ & $\mathbf{p}$ \\
\hline Kontrol 0 & $0,49 \pm 0,42$ & $0,76 \pm 0,57$ & $-2,01$ & $0,04 *$ \\
\hline Kontrol 1 & $0,83 \pm 0,57$ & $0,98 \pm 0,80$ & $-1,28$ & 0,20 \\
\hline Kontrol 3 & $1,13 \pm 0,58$ & $1,24 \pm 0,75$ & $-1,16$ & 0,25 \\
\hline Kontrol 5 & $1,33 \pm 0,66$ & $1,52 \pm 0,60$ & $-0,92$ & 0,36 \\
\hline Kontrol 10 & $1,43 \pm 0,66$ & $1,78 \pm 0,42$ & $-2,02$ & $0,04 *$ \\
\hline Kontrol 15 & $1,36 \pm 0,73$ & $1,73 \pm 0,44$ & $-1,88$ & 0,06 \\
\hline Uygulama 1 & $1,10 \pm 0,84$ & $1,63 \pm 0,65$ & $-2,35$ & $0,02 *$ \\
\hline Uygulama 3 & $1,13 \pm 0,77$ & $1,64 \pm 0,76$ & $-2,75$ & $0,01 *$ \\
\hline Uygulama 5 & $1,14 \pm 0,84$ & $1,68 \pm 0,76$ & $-2,96$ & $0,00 *$ \\
\hline Uygulama 10 & $1,18 \pm 0,85$ & $1,82 \pm 0,73$ & $-3,21$ & $0,00 *$ \\
\hline Uygulama 15 & $1,36 \pm 0,74$ & $1,72 \pm 0,83$ & $-2,17$ & $0,03 *$ \\
\hline Takip 1 & $1,03 \pm 0,90$ & $1,39 \pm 0,83$ & $-1,68$ & 0,09 \\
\hline Takip 3 & $1,23 \pm 0,87$ & $1,49 \pm 0,82$ & $-1,22$ & 0,22 \\
\hline Takip 5 & $1,19 \pm 0,92$ & $1,44 \pm 0,95$ & $-1,21$ & 0,22 \\
\hline Takip 10 & $1,11 \pm 0,80$ & $1,40 \pm 1,05$ & $-1,99$ & $0,05^{*}$ \\
\hline Takip 15 & $1,19 \pm 0,81$ & $1,14 \pm 1,12$ & $-0,32$ & 0,75 \\
\hline Takip 20 & $0,85 \pm 1,03$ & $1,05 \pm 1,20$ & $-1,01$ & 0,31 \\
\hline Takip 25 & $0,60 \pm 1,05$ & $0,92 \pm 1,27$ & $-1,31$ & 0,19 \\
\hline Takip 30 & $0,35 \pm 1,25$ & $0,89 \pm 1,29$ & $-1,53$ & 0,13 \\
\hline
\end{tabular}

*p $<0,05$

Tablo 10. Solunum Frekansının ve Periferik Deri Temperatürünün Zaman İçindeki Değişimi

\begin{tabular}{lcccc}
\hline Friedman Testi & KDM & \multicolumn{2}{c}{ Plasebo KDM } \\
& Solunum frekans1 & Periferik deri temperatürü & Solunum frekans1 & Periferik deri temperatürü \\
& & & & 153,267 \\
$\mathbf{X}^{\mathbf{2}}$ & 33,796 & 90,132 & 43,025 & $0,00^{*}$ \\
\hline
\end{tabular}

$* \mathbf{p}<\mathbf{0 , 0 5}$

\section{Tartışma}

KDM'nin OSS üzerindeki akut etkilerinin araştırıldığı çalışmamızda otonomik aktiviteyi değerlendirmek amacı ile kalp hızı, sistolik ve diastolik kan basınçları, solunum frekansı ve periferik deri temperatürü ölçüm parametreleri olarak kullanıldı. Kalp hızı, kan basıncı ve /veya solunum frekansında meydana gelen artışlar sempatik sinir sistemi aktivitesindeki artışı gösterirken, periferik deri temperatüründeki artış, sempatik aktivitedeki azalmayı göstermektedir (Wasner ve ark., 2002). Yapmış olduğumuz çalışmada da KDM ve plasebo KDM uygulamalarının OSS üzerindeki akut etkisi, bu otonomik yanıtlarda meydana gelen artma ya da azalma yönündeki değişikliklere dayanarak belirlenmeye çalışıld.

Çalışmamızda KDM ve plasebo KDM uygulamalarının her ikisinin de OSS üzerinde herhangi bir akut etkilerinin olmadığ 1 belirlendi. Kontrol fazının da çalışmaya dahil edilmiş olması sayesinde, uygulamalar sırasında meydana gelmiş olan periferik deri temperatürü artışlarının ve solunum frekansı azalmalarının benzer şekilde kontrol fazında da oluştuğu görülerek, bir seanslık KDM ya da plasebo 
KDM uygulamasının akut olarak sempatik aktiviteyi bloke ettiği şeklinde yanlış bir yoruma gidilmedi. Biofeedback üzerine yapılmış bir çalışmada da benzer şekilde, parmak ısısının istirahatte spontan olarak arttığı gösterilmiştir (Violani ve Lombardo, 2003).

Psikofizyolojik yanıtların stabilleştirilmesi amacını taşıyan on beş-yirmi dakikalık istirahati takiben, manual bir uyarı verilmeksizin, sırtı açı şekilde oturarak istirahate devam eden kişilerde sempatik aktivitenin azalması (periferik deri temperatürü artmış, solunum frekansı azalmıştır) normaldir; çünkü istirahat ile birlikte sempatik tonus azalmaktadır (Guyton ve Hall, 1996). Uygulamalar sırasında da otonomik tonusun benzer şekilde devam etmiş olması, yapılan uygulamaların otonomik tonusu değiştirmediğini göstermektedir. Takip periyodunun son on beş dakikasında açığa çıkan sempatik deşarjın ise, kişinin uzun süre sırtı açık şekilde oturmasından kaynaklanmış olabileceği düşünülebilir.

Kisner ve Taslitz (1968), dokuz sağlıklı gönüllü üzerinde, KDM'nin OSS üzerindeki akut etkisini, otonomik parametrelerden kalp hızı, kan basınc1, galvanik deri cevabı ve periferik deri temperatürünü kullanarak değerlendirmiş ve gerek KDM'nin, gerekse sırta uygulanan yüzeyel sıvazlama hareketlerinin, sempatik aktiviteyi artırdığını göstermiştir; ancak yüzeyel sıvazlamanın yapıldığı uygulamada açığa çıkan sempatik cevabın şiddeti, KDM'den daha az olarak bulunmuştur.

Holey ve ark.ları da sekiz sağlıklı gönüllü üzerinde gerçekleştirmiş oldukları çalışmalarında benzer şekilde tek seanslık KDM uygulamasının otonom sinir sistemi üzerinde akut etkilere sahip olduğunu belirlemiştir (Holey ve ark., 2011).

Dokunma kişide ilk olarak uyarılma meydana getirmektedir, ancak tekrarlanan uyarı, hiperstimülasyon analjezisi yolu ile sonuçta kişiyi gevşetmektedir (Tapan, 1988). Kisner ve Taslitz'in yapmış olduğu çalışmada, KDM uygulaması ile sempatik sistemin aktive olmuş olması bu görüş ile uyumludur, ancak KDM'yi takiben istirahat boyunca da sempatik aktivitenin yüksek olmas1, KDM'nin kişilerde hiperstimülasyon analjezisi vasıtası ile gevşeme sağladığını desteklememektedir.

KDM'nin OSS üzerindeki hem akut hem de kümülatif etkisinin bir arada değerlendirildiği çalışmada ise (Reed ve Held,1988), sağlıklı orta yaştaki kadınlara üç hafta süresince toplam dokuz seans KDM uygulanmış ve otonomik cevaplardan kalp hızı, kan basıncı, deri temperatürü ve galvanik deri cevabındaki değişiklikler izlenerek, çalışmamızdaki ile benzer sonuçlar elde edilmiş ve KDM'nin bu popülasyonda OSS üzerinde akut ya da kümülatif bir etkisi olmadığı gösterilmiştir. Söz konusu çalışmada, yapmış olduğumuz çalışmadakine benzer şekilde uygulamaya ek olarak kontrol ve takip periyotları kullanılmıştır, ancak plasebo grubunda manual uyarı yerine, bele ve gluteal sahaya, aktif olmayan ultrason aleti ile plasebo ultrason uygulaması yapılmıştır.

Literatürde KDM'nin sağlıklı olgular üzerindeki etkilerine yönelik çalışmalar oldukça azdır. Yapılmış olan çalışmalar özellikle otonomik dengesizlik ile seyreden fibromiyalji sendromu (Citak ve ark., 2006; Ekici ve ark., 2009) ; gerilim tip baş ağrısı (Akbayrak ve ark., 2002), thromboanjitis obliterans 26 gibi hastalık grupları üzerinde gerçekleştirilmiştir. Söz konusu çalışmalarda KDM'nin OSS üzerindeki etkileri yerine bireylerin günlük yaşamlarını etkileyen ağrı, fonksiyonellik seviyesi gibi parametreler üzerindeki etkinliği değerlendirilmiştir. KDM'nin OSS üzerindeki etkilerini belirlemeye yönelik çalışmalardaki sonuçların ise çelişkili olduğu gözlenmektedir. Sonuçların bu şekilde çelişkili olmasında, seçilen plasebo gruplarının çalışmadan çalışmaya farklılık göstermesi, OSS aktivitesini etkileyen değişkenlerin yeterince kontrol edilmemesi, farklı ölçüm araçlarının ve değerlendirme parametrelerinin kullanılması, çalışma metodolojilerinin farklı olması gibi faktörler rol oynamaktadır. Çalışma metodolojilerinin standardize edilmesi ile bu sorunun çözülebileceği düşünülmektedir.

\section{Sonuç}

Yapmış olduğumuz çalışmada, KDM'nin OSS üzerindeki akut etkileri sağlıklı olgular üzerinde değerlendirildi. Bilinen herhangi bir otonomik disfonksiyonu olmayan bu bireylerde, KDM'nin OSS üzerinde akut bir etkisi olmadığı görüldü. Ancak, otonomik disfonksiyonu olan farklı hasta 
popülasyonları (migren, fibromiyalji gibi) üzerinde gerçekleştirilecek çalışmalar ile de, KDM'nin OSS'yi dengeleyici yöndeki akut etkisinin değerlendirilmesi gerekmektedir. Benzer şekilde, söz konusu çalışmamızın, KDM'nin sağlıklı popülasyonda OSS üzerindeki kümülatif etkisini araştıracak bir çalışma ile desteklenmesi de gerekmektedir. Çünkü KDM, fibromiyalji ve migren gibi otonomik disfonksiyon ile seyreden hastalıkların tedavisinde, otonomik dengenin yeniden sağlanması amacı ile, en az on beş seans süresince uygulanmaktadır. KDM'nin sağlıklı kişilere de benzer şekilde yaklaşık on beş seans uygulanması ile elde edilecek kümülatif etkinin bilinmesi, KDM'nin OSS üzerindeki dengeleyici etkisinin altında yatan temelin daha iyi anlaşılmasını sağlayacaktır.

\section{Kaynaklar}

Akbayrak, T., Akarcali, I., Karabudak, R. Demirturk, F. 2002. The Results of Connective Tissue Manipulation in The Treatment of Tension Type Headache. The Pain Clinic, 13, 343-347.

Akbayrak, T., Citak, I., Demirturk, F. \& Akarcal1, I. 2001. Manual Therapy and Pain Changes in Patients With Migraine - An Open Pilot Study. Advances in Physiotherapy, 3, 49-54.

Akselrod, S., Oz, O., Greenberg, M. \& Keselbrener, L. 1997. Autonomic Response to Kawano Change of Posture Among Normal and Mild-Hypertensive Adults. Journal of Autonomic Nervous System, 64, 33-43.

Arnstein, P. 2003. The Placebo Effect. Seminars in Integrative Medicine, 1, 125-135.

Callaghan, M.J. 1993. The role of Massage in The Treatment of Athlete: A Review. Br J Sp Med, 27, 28-33.

Citak Karakaya, I., Akbayrak, T., Demirturk, F. \& Ekici, G. 2006. Short and Long-Term Results of Connective Tissue Manipulation and Combined Ultrasound Therapy in Patients With Fibromyalgia. Journal of Manipulative and Physiological Therapeutics, 29, 524-528.

Ekici, G., Bakar, Y., Akbayrak, T. \& Yuksel, I. 2009. Comparison of Manual Lymph Drainage Therapy and Connective Tissue Massage in Women With Fibromyalgia: A Randomized Controlled Trial. Journal of Manipulative and Physiological Therapeutics, 32, 127-133.

Ekici, G., Yakut, E., Akbayrak, T. 2008. Fibromiyaljili Kadınlarda Pilates Egzersizleri ve Konnektif Doku Manipulasyonunun Ağrı ve Depresyon Üzerine Etkileri: Rastgele Kontrollü Çalışma. Fizyoterapi Rehabilitasyon, 19, 47-54.

Goats, G.C., Keir, K.A.I. 1991. Connective Tissue Massage. Br J Sp Med, 25, 131-133.

Gordon, T., Kannel, W.B. 1983. Drinking and Its Relation to Smoking, BP, Blood Lipids and Uric Acid. Arch Intern Med, 143, 1366-1374.

Guyton, A.C., Hall, J.E. 1996. Guyton\&Hall Textbook of Medical Physiology. W.B. Saunders, 769-780.

Holey, A.E. 2000. Connective Tissue Massage: A Bridge Between Complementary and Orthodox Approaches. Journal of Bodywork and Movement Therapies, 4, 72-80.

Holey, L.A., Dixon, J., Selfe, J. 2011. An Exploratory Thermographic Investigation of The Effects of Connective Tissue Massage on Autonomic Function. Journal of Manipulative and Physiological Therapeutics, 34, 457-462.

Hrobjartsson, A., Gotzsche, P.C. 2001. Is The Placebo Powerless. The New England Journal of Medicine, 344, 1594-1602.

Kawano, Y., Abe, H., Kojima, S. \& Takishita, S. 1999. Effects of Propranolol on Cardiovascular and Neurohumoral Actions of Alcohol in Hypertensive Patients. Blood Pressure, 8, 37-42.

Kisner, C.D., Taslitz, N. 1968. Connective Tissue Massage: Influence of The Indroductory Treatment on Autonomic Functions. Physical Therapy, 48, 107-119.

Rajendra, A.U., Kannathal, N., Hua, L.M. \& Yi, LM. 2005. Study of Heart Rate Variability Signals at Sitting and Lying Postures. Journal of Body Work and Movement, 9, 134-141. 
Redwood, D. 2002. Methodological Changes in The Evaluation of Complementary and Alternative Medicine. The Journal of Alternative and Complementary Medicine, 8, 5-6.

Reed, B., Held, J. 1988. Effects of Sequential Connective Tissue Massage on Autonomic Nervous System of Middle-Aged and Elderly Adults. Physical Therapy, 68, 1231-1234.

Seals, D.R., Chase, P.B. 1989. Influence of Physical Training on Heart Rate Variability and Baroreflex Circulatory Control. J. Appl. Physiol, 66, 1886-1895.

Tapan, F. 1988. The Bindegewebmassage System, "Healing Massage Techniques: Holistic, Classic and Emerging Methods". California: Appleton\&Lange, 219-254.

Turner, J.A., Deyo, R.A., Loeser, J.D. \& Fordyce, W.E. 1994. The Importance of Placebo Effects in Pain Treatment and Research. JAMA, 271, 1609-1614.

Ulger, O., Sener, G., Bayramlar, K., Topuz,S. 2011. Thromboanjitis Obliterans Nedeni İle Ampute Olan Hastalarda Farklı Fizyoterapi Yaklaşımlarının Karşılaştııılması. Fizyoterapi Rehabilitasyon, 22, 65-73.

Violani, C., Lombardo, C. 2003. Peripheral Temperature Changes During Rest and Gender Differences in Thermal Biofeedback. Journal of Psychosomatic Research, 54, 391-397.

Wasner, G., Schattschneider, J., Baron, R. 2002. Skin Temperature Side Differences - A Diagnostic Tool for CRPS? Pain, 98, 19-26.

Winniford, M.D. 1990. Smoking and Cardiovascular Function. Journal of Hypertension, 9, 17-23. 